\title{
The Behavioural Effect of Multinational Operations and Its Performance on the Nigeria Economy (An Empirical Investigation)
}

\author{
Monogbe Tunde Gabriel \\ Faculty of Management Science, Department of Finance and Banking University of Port Harcourt, Choba, Rivers State, Nigeria
}

Email address:

olatundebusayo19@gmail.com

\section{To cite this article:}

Monogbe Tunde Gabriel. The Behavioural Effect of Multinational Operations and Its Performance on the Nigeria Economy (An Empirical Investigation). International Journal of Economics, Finance and Management Sciences. Vol. 4, No. 3, 2016, pp. 143-152.

doi: 10.11648/j.ijefm.20160403.17

Received: April 7, 2016; Accepted: April 16, 2016; Published: May 26, 2016

\begin{abstract}
This paper attempt to empirically investigate the behavioural effect of the multinational operations and its impact on the performance of the Nigeria economy spanning from post SAP era 1986 to 2014 using secondary data sourced from the CBN statistical bulletin. The result of the OLS shows that foreign direct investment does not significantly stimulate nor contribute to the growth of the Nigeria economy in the short run judging by $5 \%$ level of significant. Mine while, MCP and MLTLAT are positive and significantly indicators to the growth of the Nigeria economy in the short run. The result of the stationary test reveals that all the variable used in the process of research became stationary after first differencing in the order of 1(1) while we observe long run association between all the variable used in this research work as reveal by the output of the Johansson co-integration test. The output of the various diagnostic test shows that all the variable are normally distributed. The output of the granger causality test reveals that there exist a unidirectional nexus between foreign direct investment and the Nigeria economic growth with causality flowing from FDI to PCGDP. From this view, we can infer that the multinational operations (FDI) is significantly contributing to the development and growth of the Nigeria economic hence, FDI is supply leading in the long run based on the report of this study. Sequel to this, we advise that appropriate policy must be put in place so as to ensure more stability of the macro-economic variable which will serve as a prerequisite for the attraction of more multinationals.
\end{abstract}

Keywords: Multinational Operations, Granger Causality, Economic Growth

\section{Introduction}

The existence of the multinational operations in Nigeria could be linked to the Colonia era. However, the discovery of crude oil linger the interest of the colonial master on how there could benefit from the available resources. These discovery of crude oil throws Nigeria domestic investment off balance.

Before independent, the Nigeria economy was piloted with large quantum of agricultural product and commerce. The agricultural sector and commerce was capable of contributing about $48 \%$ of the aggregate gross domestic product into the Nigeria economy before the discovery of crude oil. Prior to the discovery of crude oil, the agricultural sector was forgotten as there were massive rural urban migration due to large quantum of fund in circulation (oil boom) which led to the intuition of the multinational operation in the Nigeria economy. Since the end of the World War II, foreign investment has been recognized as a very viable development path, especially for the developing countries (Oyeranti, 2003). The traditional neo-classical economics however emphasis the significances' of FDI and its ability to transform the less developed country. According to the neoclassic, foreign direct investment promote and encourage the inflow of technology, skill, materials and bridge the gap between savings, exchange rate and government spending, (Todaro, 2007). According to him, there are some certain gaps which are assumed filled prior to the operation of the multinationals which include managerial and supervisory personnel, organizational experience and expertise, 
innovation in products and production techniques. "The operation of the multinational firm in conjunction with the rapid development of some Americans and Asian countries like japan, south Korea, Taiwan, Hong Kong, Indonesia, Singapore and Malaysia after the II world war was strictly adhere to the heavy inflow of the foreign direct investment in their respective countries over the years. However, it is essential to note that the economic development of these countries has been enhanced by equipping the local economy (local investors) with series of foreign skills and technology, resources development and management expertise through sophisticated training internationally."

Mine while, it is important to note that foreign assistance is never free, it has some conditionality attached that help deepen underdevelopment of the host countries and on the other hand stimulate the multinationals corporation.

consequently, it is germane to note that for sustainable growth to take place in any economy, government of such country must equip the local investors (entrepreneur) with financial assistance as stated by Todaro, foreign skills and equipment's, ensure that the local product are transform into finish goods and encourage exportation of locally made goods so as to record favourable balance of payment which would help in stimulating economic development and achievement of required change.

Sequel to the above observations, the researcher is triggered to investigate whether the operation of the multinational frim is really "supply leading to the Nigeria economy or demand following".

\subsection{Statement to the Problem}

It has been a contemporary issues as to whether or not the multinational business has really contribute positively to the growth of the Nigeria economy and the nature of its causality flow. Taking a holistic view of the operation of the multinationals in the less developed countries, the expected rate of development is not been achieved. This can be question on some endogenous and exogenous factors. empirical investigation of Nielson and Alderson (2007), find that a strong FDI presence and export dependence contribute to low economic growth of the host countries and downsize (worse) the quality of life, including high infant mortality rate, lower food supply, inequality distribution of income, high level of environmental pollution and reduce access to some certain basic necessities of life. Wimberley and Bello (1992), argues that the penetration of the multinationals reduces the quantum of food supply in the domain of the host counties for several reasons. They added that the operations of the multinational firm brings about high level of unemployment due to the use of capital intensive strategy in a labour surplus environment. However, considering the large chain of the multinational business in some African countries like Nigeria, one wonder why the rate of development is still very minuet. This has however create a state of puzzle in the literature and among many scholar has to whether the multinational business is stimulating economy growth of the less developed nations or the multinational firm are parasite who feed on the goodies of the economy. scholars like Onu Christopher (2012), Onyali, C. I and Okafor T (2014), Ojiokoro and huang huiping, (2012) and so many more has however opted that the operations of the multinational firm has a positive influence on the economic development of our nation while other scholars like Uwubanmwen E., and ajao G. (2012), Kabir Haruna Danja, (2012), Akinlo (2004), Ugwuegbe, et al (2013), Eravwoke, K. E and Eshanake S. J (2012) find no causality flowing from the multinational operations to the growth of the economy. Sequel to the above observation, this research work is set out to investigate the direction of the causality flow that exit between the multinational operations and its impact on the performance of the Nigeria economy in the long run.

\subsection{Study Objectives}

The gross objective of this study is to empirically investigate the behavioural effect of the multinational operations and its impact on the performance of the Nigeria economy. The specific objectives is stated below

a) To empirically investigate the impact of multinational operations on the performance of the Nigeria economy

b) To statistically evaluate the effect of market capitalisation rate on the performance of the Nigeria economy

c) To empirically find out the influence of multilateral debt on the performance of the Nigeria economy

d) To statistically investigate the impact of the bilateral debt on the performance of the Nigeria economy.

e) To empirically do a brilliant investigation and make recommendations

\subsection{Research Question}

In an attempt to achieve the specific objectives of this research work, we tends to ask the following questions

a) To what extent does multinationals operation promote economic growth in Nigeria?

b) To what extent does market capitalisation rate stimulate economic growth in Nigeria?

c) To what extent does the multilateral loan influence the growth of the Nigeria economy?

d) To what extent does the bilateral loan affect the performance of the Nigeria economy?

\subsection{Research Hypothesis}

The research hypothesis are stated in their respective null form

$\mathrm{H}_{01}$ : multinational operations does not significantly promote economic growth in Nigeria

$\mathrm{H}_{02}$ : market capitalisation does not significantly influence economic performance in Nigeria

$\mathrm{H}_{03}$ : multilateral debt has no significant relationship with economic growth in Nigeria

$\mathrm{H}_{04}$ : bilateral debt does not significantly influence the Nigeria economic performance. 


\subsection{Organization of the Study}

This study is generally stratified into six different section. The section one captures the introduction, statement to the problem, objective of the study, research question and hypothesis while section two takes care of the conceptual, theoretical, empirical frame work and the point of departure. Section three contains the methodology, model specification and operational definition of term while section four comprise of the presentation of data, section five and six captures the discussion of finding, summary, conclusion and recommendations

\section{Literature Review}

For simplicity purposes, this section of the work is divided into three major part which includes the conceptual framework, the theoretical frame work, the empirical framework and finally the point of departure and criticism of some literatures. For the purpose of this research work, we will be looking at three major theory of FDI and economic growth which includes endogenous growth theory, HarrodDomar growth theory and dependency theory.

\subsection{Theoretical Underpinning}

\section{Endogenous growth theory}

The endogenous growth theory is one of the major theory that emphasis on the endogenous factors which could help in stimulating the economy. These theory however emphasis the technical progress that could emanate from the local investment, size of stock market, and stock of human capital. The theory lay much emphasis on those internal factors which could save as a sweetener and attract the operations of the multinational firm. The theory pointed out that the effectiveness of the local market is the perquisite for technical progress while economic growth comes from technological change. This theory suggest that convergence of growth rate par capital of developing and developed countries can no longer be expected to occur. The increasing returns of both human and capital implies that the rate of returns to investment in developed countries will not fall relative to developing countries. In fact the rate of returns to investment in developed counties is likely to be higher compeer to developing countries. Therefore capital need not flow from developed countries to developing countries and actually the reverse may happen.

\subsection{Harrod-Domar Theory of Growth}

Harrod and Domar attributed that investment is the prerequisite for economic growth. They therefore attribute two characteristics to investment which includes (1) investment create more income, (2) investment argument the productive capacity of an economy and hence stimulate its capital stock. The second view of harrod and domar theory of growth is also in consonant with the opinion of Nurkes's when explaining the significances of capital formation. He argues that investment will stimulate the efficiency of the nation production capacity in other to raise the stock of capital goods which will facilitate extensive production of consumables output in the future. Their turning point is that since investment exist, real income and output will continue to increase. At this point, expansion in the real income is the "demand effect" while, output expansion is the "supply effect" of investment. To achieve full employment, real income and output must expand in the same trend with stock capital. If the income and output productive capacity fails to grow in the same direction or trend, the country may experience idle capital such that investor will begin to reduce their investment expenditure which will lead to low level of income and investment in the economy.

\subsection{Dependency Theory}

Dependency theorists also focused on the several ways by which, FDI of multinational corporations affect the growth of the developing countries. The theory however emphasis on the ripple effect that could emanate from the operations of the multinational operations of the foreign firm. It has been argues that some MNC's command asset more than the national income of the host country. Some scholars of this theory believed that, distortive factors include the crowding out of national firms, rising unemployment related to the use of capital-intensive technology, and a marked loss of political sovereignty is likely to occur in an economy were the multinationals operate (Umah, 2007). It has also been argued that FDI are more exploitative and imperialistic in nature, thus ensuring that the host country absolutely depends on the home country and her capital (Anyanwu, 1993). This theory from its points of analysis could be discovered that it creates negative relationship between FDI and economy growth of the developing countries. The theory is of great belief that the economy involvement of developed countries into developing nations under multinational companies and FDI will surely resort to economy disadvantages of developing nations. The theory finally argues that foreign assistance is never free but has some conditionality attached to it.

\subsection{Empirical Critiques}

Quite a number of research work has been done on the effect of foreign direct investment and economic growth while series of result were arrived at. Quite a number of scholar find causality flowing from the operation of the multinational firm to the Nigeria economic which suggested that the existence of the multinational firm is profitable to the Nigerian economy. On the other hand, some scholars in there empirical research finds that the operation of the multinational firm is of no significant important in promoting the growth of the Nigeria economic but rather concentration on the local investor could be more profitable. This suggested that the FDI operation is "demand following" while some scholars finds dual-directional nexus between FDI and economic growth in Nigeria which implies that the relationship between the multinational operation and the Nigeria economic is symbiotic in nature. Prior to this, we 
categorise our empirical review into two different school of thought. The first school are the "crowding in school" who are of the opinion that the operation of the multinational firm promote economic growth in Nigeria while the second school comprises of scholar who opted that the operation of the multinational firm does not significantly stimulate the growth of the Nigeria economy and we called them the "crowding out school".

\subsection{Crowding in School}

Onu Christopher (2012) investigate the impact of foreign direct investment on economic growth in Nigeria using time series data spanning from 1986 to 2007 . LOS was used in analysing the short run relationship. Finding shows that foreign direct investment inject inflows of capital, marginal capacity and technical know- how which can stimulate domestic investment and trigger the pace of economic growth.

Oseghale and Amonkhienam (1987) found that Foreign Direct Investment (FDI) is positively associated with Gross Domestic Product (GDP), concluding that greater inflow of Foreign Direct Investment (FDI) will spell a better economic performance for the country.

On firm level productivity spill over, Ayanwale and Bamire (2001) assess the influence of Foreign Direct Investment (FDI) and firm level productivity in Nigeria and report a positive Spill over of foreign firms on domestic firm's productivity.

Onyali, C. I and Okafor T (2014) attempt to investigate the nexus between the inflow of foreign direct investment and its impact on the Nigeria economy using secondary data. Ordinary lease squeal estimating tools was used and findings reveals that there exist a causality flow from FDI to the Nigeria economy and hence that will help in achieving the vision 20:20 objective of the federal government. Sequel to this, there recommends that domestic investment should be encouraged.

Oji-okoro and huang huiping, (2012) did an empirical investigation on the contribution of foreign direct investment on the Nigerian economy using a secondary data from 1980 to 2009. ordinary leas square estimating tools were used in analysing and findings shows that there is a positive nexus between foreign direct investment and the Nigeria economy.

Aluko (1961), Brown (1962) and Obinna (1983) cited in Adeolu (2007) report positive linkages between Foreign Direct Investment (FDI) and economic growth in Nigeria.

Oseghale and Amonkhienam (1987) found that Foreign Direct Investment (FDI) is positively associated with Gross Domestic Product (GDP), concluding that greater inflow of Foreign Direct Investment (FDI) will spell a better economic performance for the country.

Ayanwale and Bamire (2001) assessed the influence of FDI on firm level productivity in Nigeria and reported positive spill over of foreign firms on domestic firm productivity.

Lipsey, (2002) concludes that there are positive effects, but there is not a consistent relationship between FDI stock and economic growth. The potential positive or negative effects on the economy may also depend on the nature of the sector in which investment takes place, according to Hirschman (1958) that stated the positive effects of agriculture and mining are limited.

\section{6. "Crowding Out School”}

List of scholars who canvas support for non-significances of FDI on the Nigerian economy

Uwubanmwen E., and ajao G. (2012) in there write up tittle, the determinant and impact of foreign direct investment in Nigeria using time series data spanning from 1970 to 2007. vector error correction model (VEC) and granger causality test was introduce so as to know the causality flow between the multinational investment and its developmental effect on the host economy. Output of the result reveals that although there is a long run nexus between multinational operations in Nigeria but, there operation does not have a positive and significant relationship to promote and develop the Nigeria economy. hence, they recommend that stable policy should be enact which will bring about stable macroeconomic variable such that it will attract more inflows of FDI and also injection of more expenditure on the infrastructural development which will accelerate growth that will encourage local investors and hence reduce over depending on the multinationals.

In the work of Kabir Haruna Danja, (2012) titled foreign direct investment and the Nigeria economy using time series data covering over 30 years. Empirical finding reveals that foreign direct investment does not significantly contribute to the growth and development of the Nigerian economic.

Shiro abass, (2007) investigate the impact of foreign direct investment on the Nigeria economy using time series that spanning from 1970 to 2005. Ordinary lease square estimating tools was used and analysing the data and the output of the result reveals that though foreign direct investment is a good indicator of economic development, it influence is not much felt on the growth of the Nigeria economy hence, he recommended that authority should make the economic more suitable for local investors first before thinking of the multinationals.

Akinlo, (2004) carried out an empirical study on how the multinational business can impact on the Nigerian economy using secondary data ranging from 1970 to 2001. The major estimating tools used for the basis of judgement was (ECM) which justifies the fact that there is a small and insignificant impact of the private capital and lagged foreign capital on the Nigerian economic growth while export positively impacted growth as stated by the output of the studies.

Ugwuegbe, et al (2013) investigate the impact of foreign direct investment on the Nigeria economy using annual data sourced from CBN statistical bulletin spanning from 1981 to 2009 . OLS and granger causality test was apply to justify the flow of causality. Findings reveals that has a positive but insignificant relationship to economic growth in Nigeria.

Eravwoke, K. E and Eshanake S. J (2012) empirically 
investigate the effect of foreign direct investment on the growth of the Nigeria economy. unit root test and granger causality test was conduct and finding shows that the operations of the multinationals does not granger cause growth of the economic which suggest that the little growth the economic is expose to was as a result of the operation of the local investors. Hence, there advice that government should stabilize the macroeconomic policy in the country so as to make the country a convenience zone for the local investors in other to promote economic growth in Nigeria.

Adelegan, (2000) the output of his empirical investigation reveals that the operation of the multinational firm in Nigeria is negatively influencing the overall investment. Sequel to this, he concluded that there operation is pro-consuming and pro-importing.

Ezirim, Emenyeonu and Muoghalu (2006) studied the determinants of FDI in Nigeria and found that FDI relates positively with exchange rates, inflation rates, and expected rates of return on Investments; on the contrary, FDI relates negatively with the rate of economic growth, interest rates, socio-political index, taxation and previous FDI. Based on these results, sequel to the final findings, they concluded that FDI occur in order to take an advantage and exploit the benefits associated with macro-economic variable in their quest for maximum profits in the host economies.

\subsection{Point of Departure and Criticism of Some Literatures}

Large number of authors emphasis the benefit that multinational companies can inject into the host country but fail to look at the large quantum of wealth this so called multinational companies are capable of mopping out of the host country. Sequel to this we intend to see how the FDI has contributed to the development and growth of the Nigerian economy and its ripper effect or the sycophant effect that the existence of the multinational companies has cost the host countries. All other writer are looking at the sweetener that could attract more operations of the multinational companies to invest in the Nigerian economy while we deem it fit to look at the causality flow between the operation of the multinationals and the host country.

Mine while, many researcher who tries to investigate the effect of multinational businesses and its performance on the Nigeria economy like Macaulay Egbo D (2000). Just look at it in form of advocacy paper and no sophisticated econometrics tools was used in actualising the objective of the study. Ugwuegbe S, Okore. A, and John O, (2013) studied the impact of FDI on the Nigeria economy between 1981 to 2009 but only used ordinary lease square estimator which is not a good perquisite for capturing the long-run impact of foreign direct investment on the Nigeria economy. However, ONU Christopher (2012), investigated the impact of foreign direct investment on the economic growth of Nigeria spanning from 1986 to 2007. He formulated a very good model but only used ordinary lease square method in capturing the effect of FDI on the growth of the Nigeria economy which is not sufficient enough. Eravwoke Kester and Eshanake Samuel (2012) in there paper titled Foreign Direct Investment Granger and Nigerian Growth find no causality in both direction from FDI to economic growth and from GDP to FDI. Based on the above observation, we intend to diversify by using more sophisticated estimating tools in investigating the Multinational effect, granger causality and its performance on the Nigeria economy using primary data spanning from 1986 to 2014.

\section{Research Methodology}

\subsection{Research Design}

These research work adopt the investigative econometrics research design also known as ex post facto research design in an attempt to evaluate the potential relations between variable uses in the process of research using time series data ranging from 1986 to 2014.

\subsection{Sources of Data and Operational Captures of Variables}

In this research work, we used a secondary source data obtained from the central bank of Nigeria statistical bulletin ranging from 1986 to 2014 (post SAP) age. In an attempt to achieve the gross objective of this study, we used four different independent variable which were proxy for the operation of the multinational firm in Nigeria and one dependent variable. The indicator of the multinational operation includes foreign direct investment (FDI), market capitalisation (MCP), external debt which is divided into multilateral and bilateral debt i.e. (MLTLAT), and (BILAT) while per capital gross domestic product (PCGDP) was used as a proxy for economic performance

\subsection{Operational Measures of Variable}

The variables used in the process of research are defined and measured thus

PCGDP: This is the total output level of goods and services produce in an economy over a long period of time measure in monetary term. It is measure thus real gross domestic product divided by the total population i.e. RGDP/POP*100

$\mathrm{MCP}$ : It is captured as a ratio of gross domestic product thus MCP/RGDP*100

FDI: This is the quantum of across the border transaction flowing from a foreign country to another country for the purpose of making profit. FDI is measure as a ratio of gross domestic product thus FDI/RGDP*100

MLTLAT: This is the volume of debt grant to Nigeria from various foreign country over a long period of time. This is also capture as a ratio of RGDP thus. MLTLAT/RGDP*100

BILAT: This is the lump sum of loan issue to Nigeria from the foreign club and other foreign associations such as Paris club, IMF loan, London club etc. funds obtained from this creditors are usually for economic development purposes. It is also measure has a ratio of real gross domestic product thus. BILAT/RGDP*100 


\subsection{The Model}

Based on the above empirical frame work and the reviewed literature, we formulate a model thus haven give a proper definition of our operational measures. Per capital gross domestic product is a function of multinational operation indicators in Nigeria. The model is first formulated in functional form

$$
\mathrm{PCGDP}=\mathrm{f}(\text { FDI, MCP, MLTLAT, BILAT })
$$

The model is however transform into a mathematical form by introducing constant term and intercept thus

$$
\mathrm{PCGDP}=\beta \mathrm{o}+\beta \mathrm{BFDI}+\beta 2 \mathrm{MCP}+\beta 3 \mathrm{MLTLAT}+\beta 4 \mathrm{BILAT}
$$

Since we are only trying to mimic reality, Mathematical model is assumed to be too exact and more accurate hence, we translate the above model into finametrics form by introducing error term.

$$
\mathrm{PCGDP}=\beta \mathrm{o}+\beta \mathrm{iFDI}+\beta 2 \mathrm{MCP}+\beta 3 \mathrm{MLTLAT}+\beta 4 \mathrm{BILAT}+\mu \mathrm{i}
$$

The above model is further transform into single log linear model thus

$$
\begin{gathered}
\mathrm{LOG}(\mathrm{PCGDP})=\beta \mathrm{o}+\beta \mathrm{BFDI}+\beta 2 \mathrm{MCP} \\
+\beta 3 \mathrm{MLTLAT}+\beta \text { BILAT }+\mu \mathrm{i}
\end{gathered}
$$

Where

PCGDP = per capital gross domestic product

$\mathrm{FDI}=$ foreign direct investment

$\mathrm{MCP}=$ market capitalization ratio

MLTLAT $=$ multilateral loan

BILAT $=$ bilateral loan

$\mathrm{Bo}=$ constant term

$\mathrm{B} 1-\beta 4=$ coefficients of predictors

\subsection{Apriori Expectation}

Sequel to the above review empirics and theories, independent variable is expected to have a direct nexus with the regressand criterion variable which is mathematically stated thus:

$$
\beta 1, \beta 2, \beta 3 \text {, and } \beta 4>0 \text {. }
$$

The above mathematical equation implies that we expect a positive relationship flowing from the exogenous variable to the gross domestic product.

\begin{tabular}{|c|c|c|c|c|c|}
\hline YEARS & PCGDP & FDI & МCP & MLTLAT & BILAT \\
\hline 1990 & 3628.644 & 1099.967 & 4.960287 & 10.53112 & 80.34086 \\
\hline 1991 & 3527.694 & 2218.811 & 7.028968 & 12.00654 & 87.9368 \\
\hline 1992 & 3523.347 & 3759.406 & 9.2502 & 26.46811 & 134.8957 \\
\hline 1993 & 3482.513 & 5194.722 & 13.86699 & 23.78008 & 161.058 \\
\hline 1994 & 3415.751 & 6.438954 & 19.20459 & 28.11361 & 159.8228 \\
\hline 1995 & 3391.719 & 21.55995 & 51.21653 & 27.55075 & 175.9713 \\
\hline 1996 & 3441.289 & 30.30633 & 77.82801 & 27.94782 & 140.1585 \\
\hline 1997 & 3445.782 & 29.23344 & 74.61027 & 25.46092 & 132.264 \\
\hline 1998 & 3447.857 & 20.78642 & 67.59853 & 23.99516 & 138.9562 \\
\hline 1999 & 3395.612 & 23.60471 & 76.31452 & 91.88138 & 563.7556 \\
\hline 2000 & 3466.414 & 28.1212 & 114.5442 & 91.9271 & 659.2634 \\
\hline 2001 & 3532.521 & 30.67156 & 153.4346 & 72.60751 & 663.0197 \\
\hline 2002 & 3597.341 & 49.85165 & 169.3043 & 83.15813 & 787.3536 \\
\hline 2003 & 3835.8 & 52.19867 & 274.6005 & 83.60997 & 821.0847 \\
\hline 2004 & 3978.733 & 47.04965 & 400.4132 & 72.83231 & 854.0924 \\
\hline 2005 & 4124.257 & -0.34189 & 516.0892 & 58.84263 & 420.7673 \\
\hline 2006 & 4255.857 & -6.90133 & 859.471 & 55.75832 & 20.01318 \\
\hline 2007 & 4409.107 & -17.2111 & 2078.311 & 59.01513 & 10.18327 \\
\hline 2008 & 4547.73 & -18.5428 & 1422.638 & 69.11006 & 8.731961 \\
\hline 2009 & 4734.181 & -31.5855 & 977.8909 & 72.90948 & 9.212013 \\
\hline 2010 & 4974.88 & -17.6509 & 1277.577 & 81.85278 & 7.006011 \\
\hline 2011 & 5202.133 & -15.0662 & 1231.893 & 86.69396 & 20.82779 \\
\hline 2012 & 5395.387 & -27.1118 & 1665.104 & 81.82367 & 33.70288 \\
\hline 2013 & 5612.654 & -20.3229 & 2007.917 & 102.8355 & 41.73517 \\
\hline 2014 & 5863.516 & -24.8926 & 1654.584 & 112.0002 & 47.96843 \\
\hline
\end{tabular}

\section{Data Presentation}

Table 1. Per capital Gross domestic product (PCGDP), foreign direct investment (FDI), market capitalization ratio (MCP), multilateral loan (MLTLAT) and bilateral loan (BILAT). 1986-2014.

\begin{tabular}{llllll}
\hline YEARS & PCGDP & FDI & MCP & MLTLAT & BILAT \\
\hline 1986 & 3194.696 & 93.25782 & 2.637908 & 1.811894 & 14.26864 \\
1987 & 3082.852 & 37.57813 & 3.203125 & 3.430273 & 35.94047 \\
1988 & 3221.546 & 139.9005 & 3.63095 & 3.627973 & 45.01089 \\
1989 & 3353.295 & 386.5939 & 4.33766 & 7.276966 & 74.18757 \\
\hline
\end{tabular}

Source: CBN statistical bulletin (2014)

\begin{tabular}{|c|c|c|c|c|}
\hline \multicolumn{5}{|c|}{ Dependent Variable: LOG (PCGDP) } \\
\hline \multicolumn{5}{|c|}{ Method: Least Squares } \\
\hline \multicolumn{5}{|c|}{ Date: 04/01/16 Time: $17: 44$} \\
\hline \multicolumn{5}{|c|}{ Sample (adjusted): 19862014} \\
\hline \multicolumn{5}{|c|}{ Included observations: 29 after adjustments } \\
\hline Variable & Coefficient & Std. Error & t-Statistic & Prob. \\
\hline $\mathrm{C}$ & 8.085159 & 0.023636 & 342.0645 & 0.0000 \\
\hline FDI & $1.09 \mathrm{E}-05$ & $1.02 \mathrm{E}-05$ & 1.061075 & 0.2992 \\
\hline $\mathrm{MCP}$ & 0.000134 & $3.82 \mathrm{E}-05$ & 3.509208 & 0.0018 \\
\hline MLTLAT & 0.002887 & 0.000769 & 3.752578 & 0.0010 \\
\hline BILAT & -0.000187 & $7.77 \mathrm{E}-05$ & -2.404293 & 0.0243 \\
\hline R-squared & 0.905813 & \multicolumn{2}{|c|}{ Mean dependent var } & 8.268739 \\
\hline Adjusted R-squared & 0.890115 & \multicolumn{2}{|c|}{ S. D. dependent var } & 0.185118 \\
\hline S. E. of regression & 0.061364 & \multicolumn{2}{|c|}{ Akaike info criterion } & -2.588387 \\
\hline Sum squared resid & 0.090374 & \multicolumn{2}{|c|}{ Schwarz criterion } & -2.352646 \\
\hline Log likelihood & 42.53161 & \multicolumn{2}{|c|}{ Hannan-Quinn criter. } & -2.514556 \\
\hline F-statistic & 57.70313 & \multicolumn{2}{|c|}{ Durbin-Watson stat } & 1.067029 \\
\hline Prob (F-statistic) & 0.000000 & & & \\
\hline
\end{tabular}

In other to actualise the objective of our study, we first test for the short run relationship between multinational operation indicators and gross domestic product using ordinary least square (OLS)

Table 2. Ordinary least square.

Source: author's computation

The result of table 2 above is explained below judging by $5 \%$ level of significant.

The ordinary least square estimating tool help in accessing the short run relationship between all the variable used in the process of research and to determine the fitness of the model. from the output of the result it is discovered that of all the variable used in the process of research, only market 
capitalisation (MCP) with a probability value of 0.0018 and multilateral debt (MLTLAT) with the probability value of 0.0010 has a positive and significant effect in promoting the Nigeria economy judging by $5 \%$ level of significant in the short run. This suggest that the non-significances of external debt which is the combination of multilateral debt and bilateral debt should be blame on the bilateral debt only because the output of this result reflect that multilateral debt is a good indicator which could possibly and significantly promote the growth of the Nigerian economy hence, MCP and MLTLAT are supply leading in the short run. This result is however in line with theory and our apriori expectation. On the other hand, foreign direct investment (FDI) with the probability value of (0.299) though is positive but, has no significant influence in promoting the growth of the Nigerian economy in the short run. This is against our apriori expectation. However, This suggest that in the short run, increase in the operation of the multinational firm in Nigeria is just to pest on the efficiency and existing growth of the economy at that point in time. Hence, the operation of the multinational firm in the short run is "demand following" This justifies the opinion of the Marxist in the dependency theory who opted that no foreign assistance or aids come for free but rather, there are some condition attached to it. Mine while, bilateral loan is significant but negatively related to economic growth in Nigeria which implies that $1 \%$ increase in bilateral debt will bring about 0.0018 unit decrease on the growth of the Nigeria economy all things been equal. Viewing from the global statistic, the adjusted R square is $0.89 \%$ suggesting that about $89 \%$ fluctuation in the dependent variable is captured and analyse by the independent variable while $11 \%$ is explained by all other variable not captured in our model. The value of the $\mathrm{F}$ statistic reveals the general significances of the model used in the process of research while the value of the Durbin Watson shows presence of serial correlation.

Table 3. Unit root test Times series data are usually assume to have a problem of stationality. Due to this effect, we proceed to test for stationality of our data so as to avoid having spurious result. On this note, Phillip perron unit root test is used judging by $5 \%$ level of significant.

\begin{tabular}{llllll}
\hline Variable & $\begin{array}{l}\text { phillip p } \\
\text { stat }\end{array}$ & $\begin{array}{l}\text { Adj T- } \\
\text { stat@5\% }\end{array}$ & $\begin{array}{l}\text { prob } \\
\text { value }\end{array}$ & order & remark \\
\hline D (LOG) PCGDP & -4.05667 & -2.97626 & 0.0043 & $1(1)$ & stationary \\
D (FDI) & -5.50402 & -2.97626 & 0.0001 & $1(1)$ & stationary \\
D (MPC) & -5.94334 & -2.97626 & 0.0000 & $1(1)$ & stationary \\
D (MLTLAT) & -5.75743 & -2.97626 & 0.0001 & $1(1)$ & stationary \\
D (BILAT) & -3.33037 & -2.97626 & 0.0233 & $1(1)$ & stationary \\
\hline
\end{tabular}

Source: author's computation

From the above result, we observe that the entire variable used in the process of research has a unit root but was not stationary at level. This is due to the fact that the observed value is greater than its probability value at level hence, we accept null hypothesis. Consequently, the data became stationary at first difference in the order of 1(1) and has no unit root. Sequel to this, we do not accept null hypothesis but rather we accept the alternative. Hence, we proceed to test for long run association between the variable used in the process of research using Johansson co-integration test.

Table 4. Johansen co-integration test.

\begin{tabular}{|c|c|c|c|c|}
\hline \multicolumn{5}{|c|}{ Date: 04/01/16 Time: $17: 38$} \\
\hline \multicolumn{5}{|c|}{ Sample (adjusted): 19892014} \\
\hline \multicolumn{5}{|c|}{ Included observations: 26 after adjustments } \\
\hline \multicolumn{5}{|c|}{ Trend assumption: Linear deterministic trend } \\
\hline \multicolumn{5}{|c|}{ Series: LOG (PCGDP) FDI MCP MLTLAT BILAT } \\
\hline \multicolumn{5}{|c|}{ Lags interval (in first differences): 1 to 2} \\
\hline \multicolumn{5}{|c|}{ Unrestricted Cointegration Rank Test (Trace) } \\
\hline Hypothesized & & Trace & 0.05 & \\
\hline No. of CE(s) & Eigenvalue & Statistic & Critical Value & Prob.** \\
\hline None * & 0.889318 & 106.6604 & 69.81889 & 0.0000 \\
\hline At most $1 *$ & 0.590651 & 49.43203 & 47.85613 & 0.0353 \\
\hline At most 2 & 0.431912 & 26.20916 & 29.79707 & 0.1226 \\
\hline At most 3 & 0.277852 & 11.50672 & 15.49471 & 0.1822 \\
\hline At most 4 & 0.110451 & 3.043053 & 3.841466 & 0.0811 \\
\hline \multicolumn{5}{|c|}{ Trace test indicates 2 cointegrating eqn(s) at the 0.05 level } \\
\hline \multicolumn{5}{|c|}{ * denotes rejection of the hypothesis at the 0.05 level } \\
\hline \multicolumn{5}{|c|}{ ** MacKinnon-Haug-Michelis (1999) p-values } \\
\hline \multicolumn{5}{|c|}{ Unrestricted Cointegration Rank Test (Maximum Eigenvalue) } \\
\hline Hypothesized & & Max-Eigen & 0.05 & \\
\hline No. of $\mathrm{CE}(\mathrm{s})$ & Eigenvalue & Statistic & Critical Value & Prob.** \\
\hline None * & 0.889318 & 57.22839 & 33.87687 & 0.0000 \\
\hline At most 1 & 0.590651 & 23.22287 & 27.58434 & 0.1642 \\
\hline At most 2 & 0.431912 & 14.70244 & 21.13162 & 0.3103 \\
\hline At most 3 & 0.277852 & 8.463664 & 14.26460 & 0.3335 \\
\hline At most 4 & 0.110451 & 3.043053 & 3.841466 & 0.0811 \\
\hline \multicolumn{5}{|c|}{$\begin{array}{l}\text { Max-eigenvalue test indicates } 1 \text { cointegrating eqn(s) at the } 0.05 \text { level } \\
* \text { denotes rejection of the hypothesis at the } 0.05 \text { level } \\
* * \text { MacKinnon-Haug-Michelis (1999) p-values }\end{array}$} \\
\hline
\end{tabular}

The co-integration test seeks to empirically explain the long-run nexus/association between the set of variable used in the process of research. The result of the Johansson cointegration table above reflect that two co integrating equation occurs judging by $5 \%$ level of significant and with the fact that the value of the trace statistic is higher than that of the critical value. Hence, there is a long run nexus between all the variable used in the process of research hence we proceed to error correction model.

Table 5. Parsimonious error correction model (ECM).

\begin{tabular}{|c|c|c|c|c|}
\hline \multicolumn{5}{|c|}{ Dependent Variable: LOG (PCGDP) } \\
\hline \multicolumn{5}{|c|}{ Method: Least Squares } \\
\hline \multicolumn{5}{|c|}{ Date: 04/07/16 Time: 09:03 } \\
\hline \multicolumn{5}{|c|}{ Sample (adjusted): 19872014} \\
\hline \multicolumn{5}{|c|}{ Included observations: 28 after adjustments } \\
\hline Variable & Coefficient & Std. Error & t-Statistic & Prob. \\
\hline $\mathrm{C}$ & 8.090244 & 0.023273 & 347.6265 & 0.0000 \\
\hline FDI & 5.77E-06 & 9.67E-06 & 0.596245 & 0.5571 \\
\hline MCP & 0.000117 & $3.56 \mathrm{E}-05$ & 3.273547 & 0.0035 \\
\hline MLTLAT & 0.003098 & 0.000718 & 4.313816 & 0.0003 \\
\hline BILAT & -0.000199 & 7.13E-05 & -2.792499 & 0.0106 \\
\hline $\operatorname{ECM}(-1)$ & 0.508115 & 0.198885 & 2.554815 & 0.0181 \\
\hline R-squared & 0.924486 & \multicolumn{2}{|c|}{ Mean dependent var } & 8.275864 \\
\hline Adjusted R-squared & 0.907323 & \multicolumn{2}{|c|}{ S. D. dependent var } & 0.184421 \\
\hline S. E. of regression & 0.056143 & \multicolumn{2}{|c|}{ Akaike info criterion } & -2.734419 \\
\hline Sum squared resid & 0.069345 & \multicolumn{2}{|c|}{ Schwarz criterion } & -2.448947 \\
\hline Log likelihood & 44.28187 & \multicolumn{2}{|c|}{ Hannan-Quinn criter. } & -2.647148 \\
\hline F-statistic & 53.86719 & \multicolumn{2}{|c|}{ Durbin-Watson stat } & 1.534684 \\
\hline Prob (F-statistic) & 0.000000 & & & \\
\hline
\end{tabular}

Source: author's computation 
From the above result, the speed of adjustment from short run disequilibrium position to long run equilibrium state is $51 \%$. This is indicated by the value of the $\operatorname{ECM}(-1)$ which is significant. This implies that the error correction term is significant which gives the validity that dependent variable has a long-run nexus with all other exogenous variable. However, MCP and MLTLAT remains positive and significant in promoting Nigeria economic growth, FDI is positive but has no significant ability in predict economic growth in Nigeria while BILAT is also significant but negative hence has an inverse relationship with economic growth in Nigeria.

\section{Diagnostic Test}

In order to check the adequacy of a chosen model and the data for analysis, researchers can apply a range of diagnostic tests. However, In accordance with some of the assumption of classical linear regression model, it is essential to carry out some diagnostic test so as to be save from spurious result.

Table 6. Heteroscedasticity Test Result.

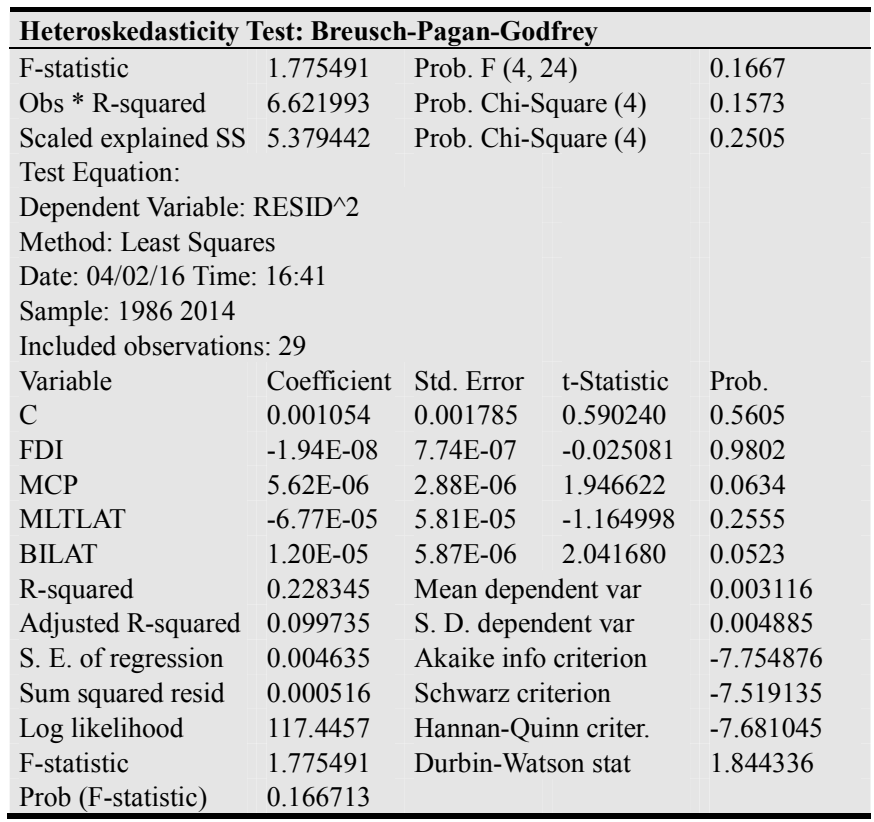

Source: author's computation

This test is conducted in other to identify whether there exist the presence of Heteroscedasticity or not. From the output, the value of the Obs R-square is 0.1573 which is greater than the $5 \%$ level of significant. This suggested that we accept the null hypothesis. This implies that, there is absence of Heteroscedasticity problem but rather there exist the present of homoscedasticity judging by 5\% level of significant.

Table 7. Granger causality test.

\begin{tabular}{llll}
\hline Pairwise Granger Causality Tests & & & \\
\hline Date: 04/02/16 Time: 18:44 & & & \\
\hline Sample: 1981 2014 & & & \\
\hline Lags: 1 & Obs & F-Statistic & Prob. \\
\hline Null Hypothesis: & 28 & 2.30358 & 0.1416 \\
\hline
\end{tabular}

\begin{tabular}{llll}
\hline \multicolumn{4}{l}{ Pairwise Granger Causality Tests } \\
\hline Date: 04/02/16 Time: 18:44 & & \\
\hline Sample: $\mathbf{1 9 8 1} \mathbf{2 0 1 4}$ & & & \\
\hline Lags: 1 & & & \\
\hline PCGDP & & & \\
PCGDP does not Granger Cause MLTLAT & 2.18501 & 0.1518 \\
MCP does not Granger Cause PCGDP & 28 & 0.37607 & 0.5453 \\
PCGDP does not Granger Cause MCP & & 9.06535 & 0.0059 \\
FDI does not Granger Cause PCGDP & 28 & 5.17716 & 0.0317 \\
PCGDP does not Granger Cause FDI & & 0.30436 & 0.5861 \\
BILAT does not Granger Cause PCGDP & 28 & 2.08824 & 0.1609 \\
PCGDP does not Granger Cause BILAT & & 1.53825 & 0.2264 \\
\hline
\end{tabular}

Source: author's computation

Granger causality test is run so as to identify the long run flows and direction of causality between all the variable used in the process of research. From the result above, it was observe that there is no causality flow between PCGDP, MLTLAT and BILAT judging by $5 \%$ level of significant. On the other hand, unilateral directional nexus exist between and multinational operation which was proxy with (FDI) and economic growth with causality flowing from FDI to the Nigeria economy. this suggest that the operation of the multinationals is significantly contributing to the quantum of growth visible in the Nigeria economy while there also exist a unilateral relationship between MCP and PCGDP with causality flowing from PCGDP to MCP. This suggest that market capitalisation rate is demand following.

Table 8. Impulse response.

\begin{tabular}{|c|c|c|c|c|c|}
\hline Period & $\begin{array}{l}\text { LOG } \\
\text { (PCGDP) }\end{array}$ & MLTLAT & МСР & FDI & BILAT \\
\hline \multirow[t]{2}{*}{1} & 0.025374 & 0.000000 & 0.000000 & 0.000000 & 0.000000 \\
\hline & $(0.00345)$ & $(0.00000)$ & $(0.00000)$ & $(0.00000)$ & $(0.00000)$ \\
\hline \multirow[t]{2}{*}{2} & 0.026387 & 0.003293 & 0.003151 & -0.005165 & 0.001859 \\
\hline & $(0.00681)$ & $(0.00600)$ & $(0.00498)$ & $(0.00586)$ & $(0.00473)$ \\
\hline \multirow[t]{2}{*}{3} & 0.028103 & 0.004763 & 0.009606 & -0.013559 & 0.002257 \\
\hline & $(0.00891)$ & $(0.00772)$ & $(0.00750)$ & $(0.00842)$ & $(0.00664)$ \\
\hline \multirow[t]{2}{*}{4} & 0.026789 & 0.007164 & 0.011498 & -0.019171 & -0.001603 \\
\hline & $(0.01149)$ & $(0.01055)$ & $(0.00880)$ & $(0.01075)$ & $(0.00782)$ \\
\hline \multirow[t]{2}{*}{5} & 0.022786 & 0.011477 & 0.011583 & -0.021468 & -0.003861 \\
\hline & $(0.01326)$ & $(0.01276)$ & $(0.00946)$ & $(0.01217)$ & $(0.00890)$ \\
\hline \multirow[t]{2}{*}{6} & 0.020306 & 0.015521 & 0.011735 & -0.022106 & -0.003711 \\
\hline & $(0.01452)$ & $(0.01458)$ & $(0.00980)$ & $(0.01287)$ & $(0.00911)$ \\
\hline \multirow[t]{2}{*}{7} & 0.019428 & 0.019330 & 0.011392 & -0.022393 & -0.003126 \\
\hline & $(0.01569)$ & $(0.01620)$ & (0.00977) & $(0.01312)$ & $(0.00898)$ \\
\hline \multirow[t]{2}{*}{8} & 0.018863 & 0.023115 & 0.010970 & -0.022926 & -0.002650 \\
\hline & $(0.01691)$ & $(0.01767)$ & $(0.00991)$ & $(0.01339)$ & $(0.00881)$ \\
\hline \multirow[t]{2}{*}{9} & 0.018494 & 0.026435 & 0.010990 & -0.023989 & -0.002505 \\
\hline & $(0.01824)$ & $(0.01898)$ & $(0.01033)$ & $(0.01391)$ & $(0.00879)$ \\
\hline \multirow[t]{2}{*}{10} & 0.018392 & 0.029052 & 0.011276 & -0.025530 & -0.002933 \\
\hline & $(0.01960)$ & $(0.02014)$ & (0.01088) & $(0.01476)$ & (0.00904) \\
\hline
\end{tabular}

Source: author's computation

The result of the impulse response estimate is represented to one standard deviation innovation in each of the variables (PCGDP), (FDI), (MPC), (MLTLAT), and (BILAT) 
respectively in a period of 10 years into the future. The figure in the parenthesis represents the standard error of the estimation. From the above table, it is observe that the impulse response of PCGDP to own shock in the short run is 0.02537 unit while the impulse response of PCGDP to shock emanating from all the exogenous variable is 0.0000 in the $1^{\text {st }}$ period regarded as short run. In the $2^{\text {nd }}$ period, the impulse respond of PCGDP to own shock increases to about 0.2638 unit while impulse response of PCGDP to shock evolving from all the exogenous variable is $0.00329,0.00315$, 0.00516 and 0.00185 respectively. In the long run, the impulse response to PCGDP own shock reduces to 0.0183 unit while that of the PCGDP to shock evolving from other variables like MLTLAT, MCP, FDI and BILAT are 0.02905, $0.01127,-0.02553$ and -0.00293 respectively. Mine while, we observe that from period 2 to 10 , the value of FDI and BILAT are negative all through.
Variance decomposition estimator is used in this process of research so as to forecast into the future the proportion of the forecast error allocated to own shock, relationship and how the level of shock in each of the variables could be projecting into the future. The result of the variance decomposition estimate shows the output for five variable used in the process of research which include LOG (PCGDP), (MLTLAT), (MCP), (FDI) and (BILAT) respectively for 10 periods forecasting into the future. The output reveals that in the short run, that is period 3, innovation to PCGDP account for about $85.7 \%$ variation in the fluctuation of PCGDP (own shock) while shock to other exogenous variable can cause about $1.3 \%, 4.1 \%, 8.4 \%$ and $0.3 \%$ fluctuation in PCGDP. While in the long run that is period 10 , innovation to PCGDP decreases and account for about $48.8 \%$ fluctuation in own shock while shock to other exogenous variable account for about $22.4 \%, 7.7 \%, 29.1 \%$ and $0.55 \%$ fluctuation in PCGDP.

Table 9. Variance decomposition of LOG (PCGDP).

\begin{tabular}{llllll}
\hline Period & S. E. & LOG (PCGDP) & MLTLAT & MCP & FDI \\
\hline 1 & 0.025374 & 100.0000 & 0.000000 & 0.000000 & 0.000000 \\
2 & 0.037297 & 96.34042 & 0.779656 & 0.713639 & 1.917774 \\
3 & 0.049847 & 85.71976 & 1.349603 & 4.113282 & 8.473126 \\
4 & 0.061286 & 75.81356 & 2.259277 & 6.241069 & 15.39000 \\
5 & 0.070830 & 67.10896 & 4.316963 & 7.346913 & 20.70829 \\
6 & 0.079437 & 59.88828 & 7.249916 & 8.023338 & 24.20771 \\
7 & 0.087763 & 53.96498 & 10.79058 & 8.258048 & 0.248506 \\
8 & 0.096153 & 48.80678 & 14.76865 & 8.181500 & 26.34275 \\
9 & 0.104827 & 44.17609 & 18.78488 & 7.982545 & 27.63090 \\
10 & 0.113836 & 40.07119 & 22.44268 & 7.750325 & 28.48433 \\
\hline
\end{tabular}

Source: author's computation

\section{Discussion of Findings, Summary and Conclusion}

This paper attempt to empirically investigate the operation of the multinational firm and its impact on the performance of the Nigeria economy spanning from post SAP era 1986 to 2014 using secondary data sourced from the CBN statistical bulletin. The output of our findings is discuss below.

The result of the short run estimating tools used in the process of research (OLS) reports that, foreign direct investment does not significantly stimulate nor contribute to the growth of the Nigeria economy judging by $5 \%$ level of significant. This is in line with the impression of Nielson and Alderson, (2007), who argues that a strong FDI presence and export dependence contribute to low economic growth and downsize (worse) the quality of life, including high infant mortality rate, lower food supply, inequality distribution of income. Though it is not in consonant with our apriori expectation but it has a theoretical bases and some empirical support like in the work of Uwubanmwen E., and ajao G. (2012), Kabir Haruna Danja, (2012) and Ugwuegbe, et al (2013). MCP and MLTLAT with the value of 0.0018 and 0.0010 respectively are positive and significantly indicators to the growth of the Nigeria economy in the short run. This suggest that more of multilateral loan and market capitalisation rate will help in stimulating the growth of the
Nigeria economy. This is however in consonant with our apriori expectation while BILAT loan is also significant but, negative. This implies that $1 \%$ increase in the bilateral loan into the economy will amount to about 0.00018 unit decrease in the growth of the Nigerian economy all thing been equal. The output of the stationality test reveals that all the variable used in the process of research became stationary after first differencing in the order of 1(1) while we observe long run association between all the variable used in this research work as reveal by the result of the Johansson co-integration test. The output of the various diagnostic test shows that all the variable are normally distributed and that there is absence of Heteroscedasticity problem. The impulse response and variance decomposition estimator tries to capture the volume of shock that could be allocated to the economy through the operation of the multinational firm. And finally the output of the granger causality test give the holistic view of cause and effect in the long run and it is discuss thus,

Firstly from the output of the estimator, we recorded that there is a unidirectional relationship between foreign direct investment and economic growth in Nigeria with causality flowing from FDI to PCGDP. This is however in line with our apriori expectation and has a theoretical backup like that of Harrod Domar theory of growth. From this view, we can infer that foreign direct investment is significantly contributing to the development and growth of the Nigeria economic hence, FDI is supply leading in the long-run. 
While market capitalisation is demand following due to the fact that economic growth granger cause MCP with causality flowing from PCGDP to MCP. This suggest that the expansion of the market capitalisation rate is determined by the quantum of economic growth in Nigeria. This argument is synonymous with the view of Robinson (1952) who argues that the prerequisite to financial market growth is economic growth. While the external debt which is the combination of MLTLAT and BILAT those not significantly stimulate economic growth in the long run.

\section{Recommendations}

Based on the above findings we recommend thus

Since the economic development of countries like Taiwan, Hong Kong, Singapore and Malaysia has been enhanced by equipping the local economy (local investors) with series of foreign skills and technology, resources development and management expertise through sophisticated training internationally, Local investors are easier controlled than the multinational firm hence, government should concentrate by investing on the local investors as it will help in creating more employment opportunities and help in stimulating the value of naira. This recommendation is based on the fact that the value of our market capitalisation rate is significantly promoting economic growth of the host country.

Secondly, government must ensure appropriate check and balances between the operation of the multinationals and that of the local firm so as to ensure that the local investors are not crowded out of the system as finding has reveals that the operation of the multinational firm is most likely to completely crowd out the local investor through the introduction of high level of equipment, skill, technology and unhealthy competition which the local investors do not have the financial capacity to counter.

Finally, since the output of our findings reveals that FDI stimulate growth of the economy in the long run, appropriate policy must be put in place so as to ensure more stability of the macro-economic variable which will serve as a prerequisite for the attraction of more foreign firm into the Nigeria economy.

\section{References}

[1] Adelegan, J. O. 2000, Foreign Direct Investment and Economic Growth in Nigeria: A seemingly unrelated model". African Review of Money, Finance and Banking, Supplementary issue of "Savings and Development" 2000, 5 (25). Milan, Italy.
[2] Adeolu, B. A. (2007). FDI and Economic Growth: Evidence from Nigeria. African Economic Research Consortium (AERC) Paper 165

[3] Akinlo, A. E. (2004). Foreign Direct Investment and Growth in Nigeria: An Empirical Investigation. Journal of Policy Modelling, 26, 627-639. http://dx.doi.org/10.1016/S01618938(04)0057-2.

[4] Aluko, S. A. (1961). Financial Economic Development in Nigeria. The Nigerian journal of Economic and social studies 3 (1), 39-67.

[5] Ayanwale, A. B. and Bamire, A. S. (2001). The Influence of FDI on Firm Level Productivity of Nigeria's Agro/AgroAllied Sector. African Economic Research Consortium (AERC).

[6] Eravwoke Kester Erhieyovwe and Eshanake Samuel Jimoh, (2013). Foreign Direct Investment Granger and Nigerian Growth. Journal of Innovative Research in Management and Humanities 3 (2), September, 2012. ISSN: 2141-8217.

[7] Kabir Haruna Danja, (2012). Foreign Direct Investment and the Nigerian Economy. American Journal of Economics 2012, 2 (3): $33-40$.

[8] Lipsey R (2002), "Home and Host Country Effects of FDI", Lidingö, Sweden.

[9] Oji-okoro and huang huiping, (2012). An Empirical Analysis on the Contribution of Foreign Direct Investment on Nigeria Economy.

[10] Onu Christopher, (2012). Impact of foreign direct investment on the economic growth of Nigeria. Interdisciplinary journal of contemporary research in business. 4 (5), 2012.

[11] Oseghale, B. D., and Amonikhienan, E. E. (1987). Foreign Debt, Oil Export, Direct Foreign Investment (1960-1984). The Nigerian Journal of Economic and Social Studies, 29 (3), 359380 .

[12] Onyali, C. I and Okafor T (2014), foreign direct investment and the Nigerian economy: Vision 2020 mission. International of business and management. 8 (16).

[13] Ugwuegbe S. Ugochukwu, Okore Amah Okore and John Okey Onoh (2013. The Impact of Foreign Direct Investment on the Nigerian Economy. European Journal of Business and Management www.iiste.org ISSN 2222-1905 (Paper) ISSN 2222-2839 (Online) 5 (2) 2013.

[14] Umah, K. E (2007). The Impact of Foreign Private Investment on Economic Development of Nigeria. Nigeria Journal of Economics and financial research. 1 (3).

[15] Wermberly and Bello (1992)"law and development in the light of dependency theory, law and society review. 14 (3) Ithaca, New York; cornell university press. 